\title{
Soil-plant transfer of radiocaesium in weakly contaminated forest ecosystems
}

\author{
S. Lamarque, E. Lucot and P.-M. Badot ${ }^{1}$ \\ ${ }^{1}$ University of Franche-Comté, Department of Environmental Biology, EA 3184 MRT USC \\ INRA, 2 place Leclerc, 25030 Besançon, France
}

\begin{abstract}
During the Chernobyl accident, large areas in Europe, particularly forests, were contaminated by radiocaesium. Soil-plant transfer is often the first step by which ${ }^{137} \mathrm{Cs}$ enters to food chains by incorporating the forest biogeochemical cycle. The present work is devoted to assess the soil-plant transfer of radiocaesium in weakly contaminated forest area, in the Franche-Comté region $\left(16202 \mathrm{~km}^{2}\right)$ in North Eastern France. This region has been markely contaminated after the Chernobyl accident. Twelve sites, with various functional features and high diversity of ecological contexts were selected to sample forests trees. Two species (Picea abies and Fagus sylvatica) and two organs, (leaves or needles and young branches) were sampled for radioactivity measurements. Radiocaesium activities in soils varied between 61 to $280 \mathrm{~Bq} \cdot \mathrm{kg}^{-1} \mathrm{DW}$ at $0-5 \mathrm{~cm}$ depth and between 14 to $224 \mathrm{~Bq} \cdot \mathrm{kg}^{-1} \mathrm{DW}$ at $10-15 \mathrm{~cm}$. Radiocaesium activities in leaves, needles and branches displayed high variability. We reported a large variability of Aggregated Transfer Factors $\left(T_{a g}\right)$ values with respect to vegetation type, organ type and soil features. The activity concentration in the leaves and needles were generally higher than those measured in the branches. The $\mathrm{T}_{\mathrm{ag}}$ values could be explained by the radiocaesium bioavailability variability in relation to soil type, soil features and environmental parameters.
\end{abstract}

\section{INTRODUCTION}

Radionuclides produced by nuclear explosions and nuclear facilities are released into the environment in large areas worldwide. In recent years, an increasing number of radioecological studies have focused on the impact of radionuclides because deposition and trapping or storage is often higher in natural and semi-natural ecosystems, especially forests, than in neighbouring agricultural areas [1]. Forest ecosystems are highly vulnerable to atmospheric contamination due to the high potential of interception of the canopy and the important recycling capacity of these ecosystems [2]. Soil is an important source of radionuclides in biological systems [3, 4]. More than 18 years after the Chernobyl deposition, ${ }^{137} \mathrm{Cs}$ in forest soils still showed a high availability for uptake by plants and low leaching $[5,6]$. Rate of radiocaesium vertical migration in forest soils is rather slow and weak: more than a decade after the accident, most of the Chernobyl deposition of radiocesium is still in the upper organic-rich layer of the forest soil horizon [7, 8, 9, 10]. Owing to the close chemical properties of Cs and K, which is an important element in the living organisms, ${ }^{137} \mathrm{Cs}$ is a important contributor to the internal radiation dose. ${ }^{137} \mathrm{Cs}$ migration in soils depends on the type of soil, chemical features and granulometry, sorption and desorption processes, moisture, mineral composition, etc. In situ measurements after the Chernobyl accident showed that nutrient cycling and storage led to a much longer persistence of radiocesium in forest ecosystems in comparison with cropping systems [11, 12, 13]. Consequently, it is very important to document the forest ecosystem clearance and describe the potential transfer of radiocesium and its mechanisms in forest ecosystems in order to improve risk assessment. Aggregated transfer factor $\left(\mathrm{T}_{\mathrm{ag}}\right)$ expressed in Bq. $\mathrm{kg}^{-1}$ in plant (dry weight) per Bq. $\mathrm{m}^{-2}$ in soil (dry weight) have been often used as a comparative measure of radiocaesium availability in different soils. Several factors can cause variation in $\mathrm{T}_{\mathrm{ag}}$ : radiocaesium distribution in the soil profile, radiocaesium physicochemical form in the soil, distribution of root system in the soil profile and capacity of different plants for radiocaesium accumulation [14]. 
In order to help both ecological and human health risk assessments, it is important to gather further data on the distribution of radionuclides in natural and semi-natural environments. Thus, the present work is devoted to document ${ }^{137} \mathrm{Cs}$ activity and soil-plant Aggregated Transfer Factors $\left(\mathrm{T}_{\mathrm{ag}}\right)$ in different woodland ecosystems in Franche-Comté (France) and to study the effects of environmental features on $\mathrm{T}_{\mathrm{ag}}$ values in various soils.

\section{SAMPLING AND MEASUREMENTS}

\subsection{Experimental sites}

The studied area is the Franche-Comté region, located in the Eastern part of France (Fig. 1). Geographical extent covers $16.202 \mathrm{~km}^{2}$ and topography spans range of altitude to $1.500 \mathrm{~m}$ above sea level. The sampling strategy was defined on the basis of the ecological features of the studied area. The Franche-Comté displayed a high variety of ecological contexts on a small spatial extend. The region displayed a high annual temperature gradient. Precipitations are relatively high for a temperate region and vary between 800 and $1900 \mathrm{~mm} \cdot \mathrm{an}^{-1}$ depending on the site and the season. Twelve undisturbed soils were chosen in forest ecosystems with an ecologically based sampling strategy and were sampled at 0-5 cm and 10-15 cm. These twelve sites were representative of various functional features and great diversity of ecological contexts in Franche-Comté and were selected to sample forests trees. An accurate description of each site was realized including vegetation type, elevation, climate, soil texture and soil type.

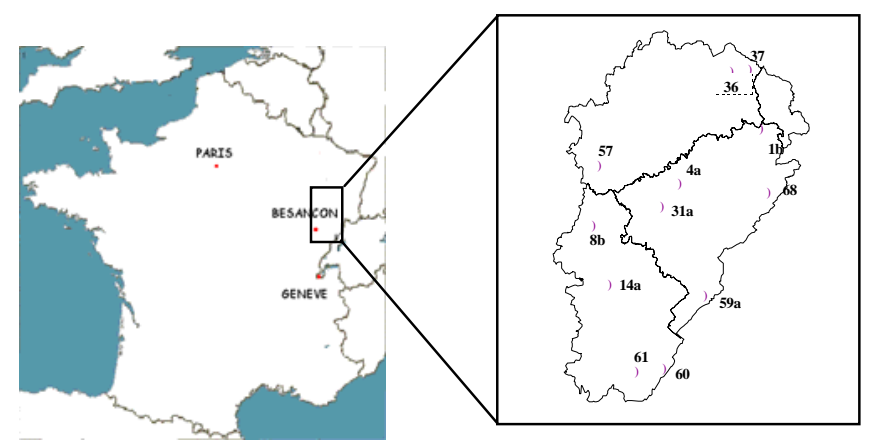

Figure 1. Localisation of the Franche-Comté region and the 12 sampling sites.

\subsection{Sampling}

In each chosen site, soil samples were collected from May to October 2001. Three samples were taken in each site. Immediately after sampling, soils were placed into a well-matched plastic bag. A Global Positioning System (Garmin, Etrex Summit) was used to define the geographical location of each sampling site. In each sites, we collected leaves (needles) and young branches of two woody species Fagus sylvatica) widespread in France: spruce (Picea abies W.) and beech (Fagus sylvatica L.). Vegetation were collected in June 2003 on 40 years old trees.

\subsection{General chemical analysis and gamma spectrometry measurements}

Before measuring caesium activity, soil and vegetation samples were dried at $105^{\circ} \mathrm{C}$ for $48 \mathrm{~h}$. Gamma analyses were carried out using a high purity germanium detector (HPGe) and a multichannel analyzer with INTERWIN 4.0 treatment software (Eurisys Mesures, Saint Quentin en Yvelines, France). The 
${ }^{137}$ Cs activity measurements were decay-corrected to May 1, 1986. Each soil sample was analysed for $12 \mathrm{~h}$ (43200 s) and vegetation sample for 24h (86400s). The counting uncertainty did not exceed $10 \%$. Soil $\mathrm{pH}$ was measured in 1:5 of soil/water ratio with a glass electrode pHmeter. The organic matter content of soil was estimated with a TOC analyser (Shimadzu, Germany). Evaluation of cationic exchange capacity and exchangeable bases of soil was determinated by cobaltihexamin method [15]. Granulometry was determinated by Robinson pipette method.

\section{RESULTS}

Climatic conditions, soil properties and radiocaesium activities in soil and litter at each sampling sites are shown in Table 1.

Table 1. Environmental and soil features of the 12 selected sites and activities of caesium in soil and litter $\left(\mathrm{CEC}=\mathrm{cmol} . \mathrm{kg}^{-1}\right)$.

\begin{tabular}{|c|c|c|c|c|c|c|c|c|c|c|c|}
\hline Site & $\begin{array}{c}\text { Elevation } \\
\mathrm{m}\end{array}$ & $\begin{array}{c}\text { Pluviometry } \\
\mathrm{mm}\end{array}$ & $\begin{array}{l}\text { Geological } \\
\text { substratum }\end{array}$ & OM15 & pH15 & Clay15 & $\begin{array}{c}\text { CEC } \\
10-15 \mathrm{~cm}\end{array}$ & Soil type & $0-5 \mathrm{~cm}$ & $\begin{array}{c}\text { Cs Bq. kg-1 } \\
10-15 \mathrm{~cm}\end{array}$ & Litter \\
\hline $4 \mathbf{a}$ & 350 & 1087 & clay calcareous & 4,6 & 4,8 & 39,2 & 10,6 & brown & 61 & 37 & 49 \\
\hline 57 & 240 & 780 & silty clay & 1,7 & 3,9 & 11,8 & 1,7 & leached brown & 70 & 14 & 42 \\
\hline 31 a & 413 & 1087 & residuals clay & 39,4 & 4,8 & 32,62 & 5,8 & leached brown & 82 & 43 & 63 \\
\hline $14 \mathrm{a}$ & 340 & 1241 & marl & 11,9 & 6,5 & 31,7 & 37,6 & pseudogley brown & 87 & 73 & 80 \\
\hline $8 \mathrm{~b}$ & 230 & 1087 & clay & 2,9 & 4,6 & 16,9 & 2,3 & pseudogley leached brown & 111 & 29 & 70 \\
\hline 36 & 560 & 1500 & volcanic formation & 16,3 & 4 & 28,7 & 3,7 & acid brown & 112 & 40 & 76 \\
\hline $1 \mathrm{~b}$ & 400 & 1021 & sandy silt & 2,9 & 4,7 & 20,7 & 4,6 & leached brown & 169 & 23 & 96 \\
\hline 60 & 890 & 1432 & calcareous & 10,0 & 4,8 & 28,8 & 15 & carbonated brown & 194 & 70 & 132 \\
\hline 68 & 1370 & 1925 & gravelly calcareous & 26,5 & 6,6 & 23,2 & 69,5 & humo-calcic & 225 & 100 & 163 \\
\hline 37 & 800 & 1700 & granite & 7,6 & 3,6 & 19,6 & 1 & acid brown & 233 & 75 & 154 \\
\hline $59 a$ & 1290 & 1925 & marl & 21,2 & 4,6 & 33 & 71,6 & carbonated brown & 268 & 211 & 240 \\
\hline 61 & 900 & 1394 & gravelly calcareous & 10,3 & 6,3 & 29,3 & 7,1 & carbonated brown & 280 & 224 & 252 \\
\hline
\end{tabular}

All soils samples were contaminated. The geographical pattern of ${ }^{137}$ Cs contamination showed high spatial variations, reflecting the marked field heterogeneity of caesium distribution (Table 1). Soils were contaminated between 61 and $280 \mathrm{~Bq} \cdot \mathrm{kg}^{-1}$ at $0-5 \mathrm{~cm}$ of depth and between 14 and $224 \mathrm{~Bq} \cdot \mathrm{kg}^{-1}$ at $10-15 \mathrm{~cm}$. Expressed in terms of surface activities, contamination varied between 6800 and 21700 Bq. $\mathrm{m}^{-2}$. Radiocaesium activities of plant organs were presented in figure 2 . The caesium contamination displayed marked spatial variations. Some organs do not present a any measurable contamination.

Table 2. $\mathrm{T}_{\mathrm{ag}}$ of leaves and branches in two seasons (spring and autumn) and two species (Picea abies and Fagus sylvatica). Values represent means $\pm S E(n=3)$. The zero values indicate no Cs contamination. The lack of data corresponds to the lack of species in the site.

\begin{tabular}{|c|c|c|c|c|c|c|c|c|c|}
\hline \multirow{3}{*}{ Sites } & \multicolumn{4}{|c|}{ Fagus sylvatica } & \multicolumn{5}{|c|}{ Picea abies } \\
\hline & \multicolumn{2}{|c|}{ Spring } & \multicolumn{2}{|c|}{ Autumn } & \multicolumn{3}{|c|}{ Spring } & \multicolumn{2}{|c|}{ Autumn } \\
\hline & Leaves & Branchs & Leaves & Branchs & Needles n-1 & Needles $\mathrm{n}$ & Branchs & Needles n-1 & Branchs \\
\hline $4 a$ & $0,0016 \pm 0,0002$ & $0,0008 \pm 0,0003$ & 0,00136 & 0,00098 & & & & & \\
\hline 57 & $0,0015 \pm 0,0003$ & $0,0013 \pm 0,0001$ & 0,00107 & 0,00022 & & & & & \\
\hline 31 a & $0,0002 \pm 0,0002$ & 0 & 0,00035 & 0 & & & & & \\
\hline $14 a$ & 0 & 0 & 0,00033 & 0,00018 & & & & & \\
\hline $8 \mathrm{~b}$ & $0,0048 \pm 0,0002$ & $0,0052 \pm 0,0006$ & 0,0068 & 0,0028 & & & & & \\
\hline 36 & $0,0024 \pm 0,0012$ & $0,0025 \pm 0,0011$ & 0,0045 & 0,0033 & & & & & \\
\hline 1b & 0 & 0 & 0,0005 & 0 & & & & & \\
\hline 60 & & & & & 0 & & 0 & 0 & 0 \\
\hline 68 & $0,0069 \pm 0,0067$ & $0,0006 \pm 0,0003$ & 0,0005 & 0,0007 & $0,0011 \pm 0,00046$ & & $0,0017 \pm 0,00069$ & 0,00121 & 0,00075 \\
\hline 37 & $0,0074 \pm 0,0016$ & $0,0026 \pm 0,0004$ & 0,0035 & 0,0011 & $0,0089 \pm 0,00139$ & $0,0257 \pm 0,0133$ & $0,0096 \pm 0,00289$ & 0,00215 & 0,0164 \\
\hline $59 a$ & $0,0036 \pm 0,001$ & $0,0008 \pm 0,0003$ & 0,0005 & 0,00028 & $0,0004 \pm 0,00046$ & 0,0002 & $0,0002 \pm 0,00017$ & 0,00035 & 0,00023 \\
\hline 61 & $0,0047 \pm 0,002$ & $0,0025 \pm 0,0005$ & 0,0044 & 0,0027 & $0,0062 \pm 0,00144$ & $0,0179 \pm 0,0024$ & $0,008 \pm 0,00167$ & 0,0054 & 0,0023 \\
\hline
\end{tabular}



AUTUMN

SPRING SPRING AUTUMN
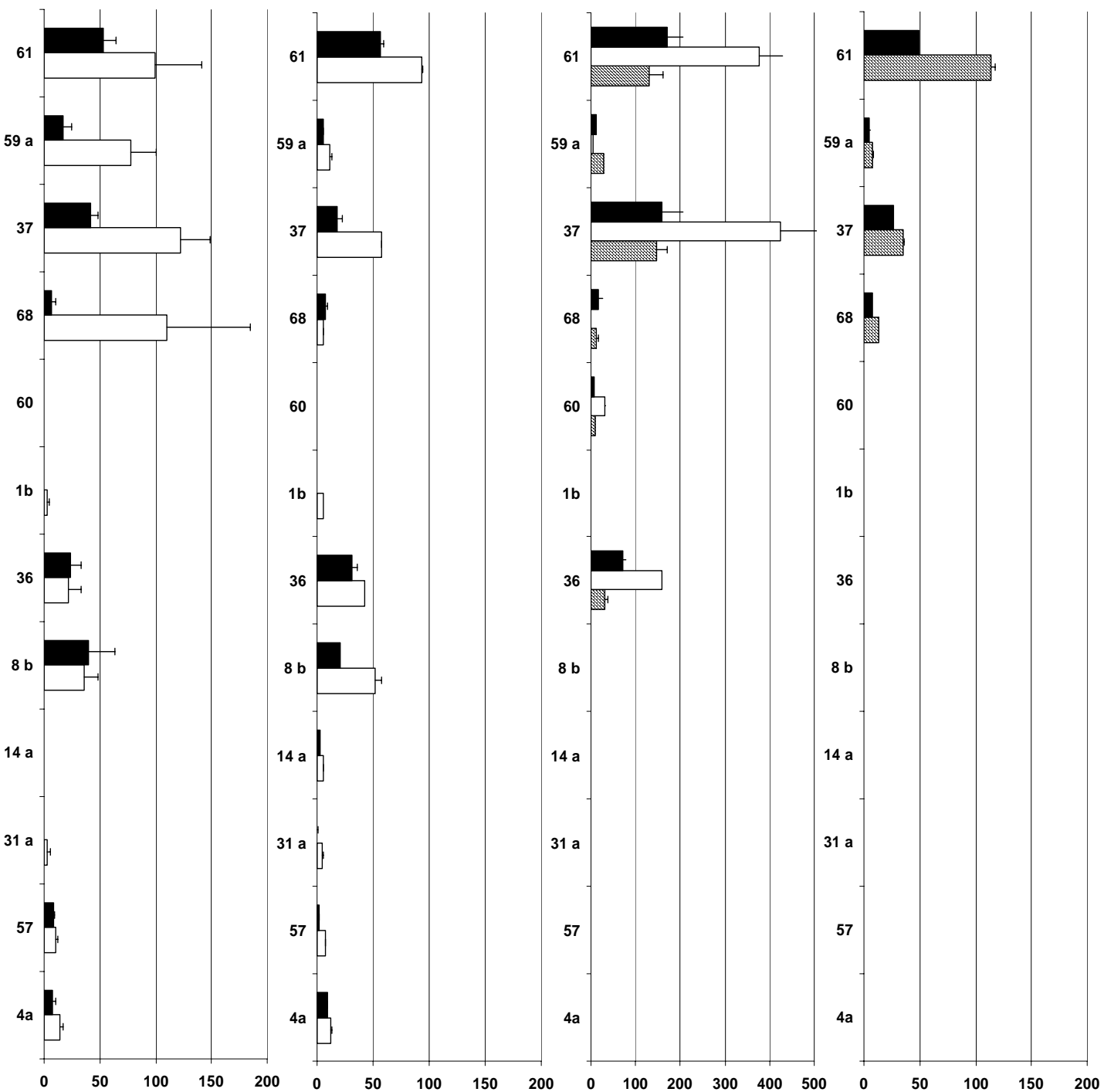

Figure 2. Caesium activities in vegetation in two seasons (spring and autumn), in two organs (leaves or needles and branches). Black, white and scratched histograms represent branches, leaves or needles (year $n$ ) and needles (year n-1) respectively. Values represent contamination means $\pm \mathrm{SE}(\mathrm{n}=3)$ in Bq. $\mathrm{kg}^{-1}$. The lack of data correspond to the lack of species in the site.

The $\mathrm{T}_{\mathrm{ag}}$ for leaves and branches in two seasons are given in Table 2. The maximum $\mathrm{T}_{\mathrm{ag}}$ for ${ }^{137} \mathrm{Cs}$ from soil to leaves is 0.0074 for Fagus sylvatica and 0.0179 for Picea abies and the maximum $\mathrm{T}_{\mathrm{ag}}$ for ${ }^{137} \mathrm{Cs}$ from soil to branches are 0.0068 for Fagus sylvatica and 0.0164 for Picea abies. Cs activities and $\mathrm{T}_{\mathrm{ag}}$ varied in a large extend depending of sites, species, organs and sampling seasons. Activities in plant organs varied with respect to sampling sites. In general, sites with high plant contaminations are sites with the highest soil contamination $(61,59 \mathrm{a}, 37)$ and in a lesser extend (68, 36 and 8b). In a given site, Picea abies organs displayed higher Cs activities than Fagus sylvatica organs. Young organs of both species (leaves of Fagus sylvatica and needles of the year of Picea abies) were highly contaminated than older organs (branches). Plant contamination also varied depending on the season. During spring, when tree growth was high, young needles and leaves displayed the highest Cs values. In general, 
sites with high contamination in plant organs displayed the highest $T_{a g}$ values. Beech $T_{a g}$ were correlated with soils features $(\mathrm{p}<0,05)$ and very strongly with $\mathrm{pH}$, exchangeable cationic capacity $\left(\mathrm{r}^{2}=1\right)$ and organic matter $\left(\mathrm{r}^{2}=0.92\right)$ at $0-5 \mathrm{~cm}$ of depth. Spruce $\mathrm{T}_{\mathrm{ag}}$ were correlated with organic matter $\left(r^{2}=-0.97\right)$ and CEC $\left(r^{2}=-0.97\right)$. $T_{a g}$ values weren't correlated with environmental parameters (elevation, pluviometry and geological substratum).

\section{DISCUSSION}

The results show that caesium can be markedly transferred from soil to plant in Franche-Comté weakly contaminated forest ecosystems. Transfer extend varies with respect to soil type, species and organs. The radionuclide detected in the different organs of trees may have two origins: the root uptake from the soil and the aerosol deposition on aerial surfaces. In this study, there is no one-to-one relation between caesium activities in soil and caesium activities in plant organs. In the case of absence of contamination in sampling, it is not possible to assert if the plants are really free of caesium contamination or if the contamination is below the detection threshold of the gamma spectrometer.

The site number 68, 59, 61 and 37 presented different characteristics. The 61/37 group presented a low CEC (around 9.1 and $0.2 \mathrm{cmol}^{\mathrm{kg}} \mathrm{k}^{-1}$ ) and a low organic matter content (below 15\%) in comparison with 68/59a group whose CEC is between 57 and $67 \mathrm{cmol}^{\mathrm{kg}} \mathrm{k}^{-1}$ and organic matter content vary between 24 and 28\%. Even, the 68/59a group litter was very strongly contaminated (120 and 461 $\mathrm{Bq} . \mathrm{kg}^{-1}$ respectively) in comparison with $61 / 37$ group (73 and $49 \mathrm{~Bq} . \mathrm{kg}^{-1}$ ). The ability to keep caesium is very different between the two groups. Soil features and particularly, exchangeable cation contents may explain site variability. 61 and 37 sites displayed a low pH (5,1 and 3,7), a low CEC and a high sand content, $50 \%$ for 37 site favouring strong caesium absorption by roots [17].

$\mathrm{T}_{\mathrm{ag}}$ measured in the present study were similar to these reported in the literature. Fogh et al. [18] measured in 10 years old Pinus transfer factor of 0.0017 for new needles and 0.0016 for branches and on 40 years old Pinus, they measured 0.002 for new needles and 0.02 to 0.05 for branches. Soil features, but not environmental parameters influence transfer factor.

Caesium activities in spruce sampling were higher than those measured in beech. This difference could be explained by the best ability of conifers in comparison of broad-leaved trees to intercept radiocaesium fallout [19]. This difference may also be due to difference in root system between the two species: beech has got a deep root system and spruce displays roots mainly located in the upper layers of soil, which are the most contaminated [20]. Roots features were genetically controlled [21] but these characteristics were modulated by soil properties [22]. $\mathrm{T}_{\mathrm{ag}}$ values of new needles are very high because they act as a strong sink for mineral nutrients in spring corresponding to a high metabolic activity related to active growth. Spruce branches displayed higher $\mathrm{T}_{\text {ag }}$ values than those observed in beech. Spruce efficiently bioaccumulate and store caesium. But, $\mathrm{T}_{\mathrm{ag}}$ values differences between two species depend of sites.

In beech, leaves showed caesium activities higher than those measured in branches. In spruce, n-1 needles were more contaminated than branches, whereas it was the opposite in spring. Likely this corresponds to sink-source changes between metabolically active organs and to the translocation of mineral ions including Cs at the beginning of the winter months. In the same way, needles of the year showed very high values in spring (424 Bq. $\mathrm{kg}^{-1}$ for site 37$)$.

$T_{a g}$ values were very high in new needles with a maximum of 0.0257 for site 37 . Organs newly developed become storage compartments during growth period and then can act as nutrients source when growth stops. Caesium contents of leaves and branches are known to decrease in autumn [23].

\section{CONCLUSION}

Caesium activities and $\mathrm{T}_{\mathrm{ag}}$ values measured in organs of forest trees highly vary with species, site, time and in side a same site. Theses variations were related to physiological features of species. In trees, caesium is highly mobile and is carried with mineral fluxes. The present results show that radionuclide transfer can be notably high in weakly contaminated forest ecosystems. Thus, such areas have to be taken into account in risk assessment policies. 


\section{Acknowledgments}

This work was supported by Regional Council of Franche-Comté, the Ministry of Education and Research and CAPM (Communauté d’Agglomération des Pays de Montbéliard).

\section{References}

[1] Bunzl K., Schimmack W., Kreutzer K., Schierl R., Sc. Tot. Environ 78 (1989) 77-87.

[2] Evans C.H., Alberts J.J., Clark R.A., Geochem. Cosmochim. Acta 47 (1983) 1041-1049.

[3] Isaksson M., Erlandsson B., and Mattson S., J. Environ. Radioactivity 55 (2001) 47-59.

[4] Bossew P., Ditto, M., Falkner, T., Henrich E., Kienzl K., and Rappelsberger U., J. Environ. Radioactivity 55 (2001) 187-194.

[5] Tikhomirov F.A., Shcheglov A.I., Sci. Tot. Environ. 157 (1994) 45-57.

[6] Belli M., Tikhomirov F.A., editors. Behaviour of radionuclides in natural and semi-natural environments (1996) p147.

[7] Thiry Y., and Myttenaere C., J. Environ. Radioactivity 18 (1993) 247-257.

[8] Ivanov Y.A., Lewyckyj N., Levchuk S.E., Prister B.S., Firsakova S.K., Arkhipov, A.N., Kruglov S.V., Alexakhin, R.M., Sandalls J., and Askbrat S., J. Environ. Radioactivity 35 (1996) 1-21.

[9] Drissner, J., Bürmann W., Enslin F., Heider R., Klemt E., Miller R., Schick G., and Zibold G., J. Environ. Radioactivity 41 (1998) 19-32.

[10] Rafferty, B., Brennan M., Dawson D., and Dowbing D., J. Environ. Radioactivity 48 (2000) 131-143.

[11] Myttenaere C., Schell W.R., Thiry Y., Sombre L., and Ronneau C., Sci. Tot. Environ. 136 (1992) 77- 82.

[12] Gerzabek M.H., Strebl F., and Temmel B., Environ. Pollution 99 (1998) 93-98.

[13] Strebl F., Gerzabek M. H., Bossew P., and Kienzl K., Sci. Tot. Environ. 226 (1999) 75-79.

[14] Fesenko S.V., Soukhova N.V., Sanzharova N.I., Avila R., Spiridonov S.I., Klein D., Badot P.M., Sci. Tot. Environ. 269 (2001) 87-103.

[15] Orsini L., Remy J.C., Science du Sol 4 (1976) 269-275.

[16] Livens F.R., Horill A.D., Singleton, Health Physics 60 (4) (1991) 539-545.

[17] Skarlov V., Papanicolaou E.P., Nobelic C., Geoderma 72 (1996) 53-63.

[18] Fogh C.L., Andersson K.G., Sc. Tot. Environment 269 (1-3) (2001) 105-115.

[19] Adriano D.C., Hoyt G.D., Pinder J.E., Health Physics 40 (1981) 369-376.

[20] Kostler J.N., Bruechner E., Bibeiriether H., Die Wurselm der, Paul Parez Hamburg (1968) p284.

[21] Zobel R.N., Genetic control of roots system in Plant Roots (1996) pp21-30.

[22] Silberbush M., Simulation of ion uptake from the soil in Plant Roots (1996) pp643-658.

[23] Fesenko S.V., Soukhova N.V., Sanzharova N.I., Avila R., Spiridonov S.I., Klein D., Badot P.-M., Radiat. Environ. Biophys. 40 (2001) 105-113. 